\title{
Antecedents of e-money adoption intention among Indonesian and Turkish consumers
}

\author{
Usep Suhud $^{a^{*}}$, Tamer Budak ${ }^{\mathrm{b}}$ and Serkan Benk ${ }^{\mathrm{c}}$
}

${ }^{a}$ Faculty of Economics, Universitas Negeri Jakarta, Indonesia

${ }^{b}$ Faculty of Law, Inonu University, Malatya, Turkey

${ }^{c}$ Faculty of Economics and Administrative Sciences, Inonu University, Malatya, Turkey

CHRONICLE ABSTRACT

\begin{tabular}{l}
\hline Article history: \\
Received: June 302019 \\
Received in revised format: July \\
302019 \\
Accepted: September 9, 2019 \\
Available online: \\
September 10, 2019 \\
\hline Keywords: \\
e-money \\
Social influence \\
Perceived usefulness \\
Adoption intention \\
Behavioural finance \\
\hline
\end{tabular}

This study aimed to measure the impact of attitude, social influence, and perceived usefulness on e-money
adoption intention. Data were collected using an online instrument involving 264 participants in Indonesia, and
287 participants in Turkey. Data were analyzed using exploratory and confirmatory factor analysis, and struc-
tural equation modeling and there were five hypotheses to be tested. The results of the study indicated a signif-
icant impact of attitude on adoption indention. Also, a significant influence of perceived usefulness on attitude
and adoption intention was also detected. Moreover, a significant effect of social influence on perceived use-
fulness and adoption intention was observed. However, there were different results when the calculation focused
on participants in each country. This study discussed recommendations for practitioners and future studies.
O 2020 by the authors; licensee Growing Science, Canada

\section{Introduction}

Electronic money or e-money is defined as "electronic store of monetary value on a technical device that may be widely used for making payments to undertakings other than the issuer without necessarily involving bank accounts in the transaction, but acting as a prepaid bearer instrument" (European Central Bank, 1998, p. 7). In general, according to European Central Bank (1998), there are two types of e-money including card-based products and software-based products. e-Money in this study refers to a card-based product. In Indonesia, Bank Indonesia (the central bank) commenced promoting e-money in 2015 as an attempt to create a cashless society (Gunawan, 2015). Since then, banks and non-banks issued e-money (Lukman, 2014) in different forms including pre-paid card and e-wallet (Wahyuningsih, 2016). In practice, the use of e-money can be mandatory, for example, for paying bus and train tickets, or voluntary, for example, for shopping. Looking at the definition of e-money above, it can be said that popular mobile money in Kenya (Osah \& Kyobe, 2017), for example, is part of e-money. When many researchers focus on consumer behaviour related to mobile money, few researchers pay attention to consumer behaviour related to e-money. From that little study, for example, Miliani et al. (2013) examined consumers' intention to adopt e-money by employing perceived benefit, perceived security and risk, and bank consideration as predictor variables. In this current study, the authors employed attitude towards adoption, social influence, and perceived usefulness to predict e-money adoption intention. Therefore, this study intends to evaluate the impact of attitude, social influence, and perceived usefulness on emoney adoption intention. This paper first gives some theoretical background on attitude and adoption intention; perceived usefulness, attitude, and adoption intention; and social influence, perceived usefulness, and adoption intention. Second, the study sets up the theoretical framework to be tested in terms of the results. Third, we present the research methods and the results from Indonesia and Turkey are discussed and finally, conclusion of the study is given.

\footnotetext{
* Corresponding author.

E-mail address: usuhud@unj.ac.id (U. Suhud) 


\section{Literature review}

\subsection{Theoretical background}

\subsubsection{Attitude and adoption intention}

Badrinarayanan et al. (2014) measured consumers' purchase intention through online shopping. By involving university students in the USA, they investigated the impact of congruity on trust and attitude, and their impact on purchase intention. They explained that attitude significantly affected purchase intentions and congruity with self-image significantly affected attitude.

Accordingly, the authors hypothesise that:

\section{$H_{1}-$ Attitude towards adoption significantly influences on e-money adoption intention.}

\subsubsection{Perceived usefulness, attitude, and adoption intention}

Perceived usefulness is determined as "the degree to which a person believes that using a particular system would enhance his or her job performance" (Davis, 1989, p. 320). Perceived usefulness is reported to have an important impact on attitude towards adoption and adoption intention (Ayeh et al., 2013; Belkhamza \& Wafa, 2015; Szajna, 1996). Furthermore, to predict the intention to use consumer-generated media for travel planning, Ayeh et al. (2013) employed perceived ease of use, perceived usefulness, perceived trustworthiness, attitude, perceived enjoyment, and perceived similarity. They documented that perceived usefulness had a significant impact on attitude and use intention. In addition, they also mentioned that attitude had a significant impact on use intention. Hsu and Lin (2008) studied intention of bloggers to use blogs. In their study, technology acceptance factors and knowledge sharing factors were linked to attitude towards using blog. Further, attitude toward using blog and social influence factors were linked to blogging intention. Social influence factors included social norms and community identifications. They found that attitude and community identification significantly impacted adoption intention. Involving participants of computer program trainings, Malhotra and Galletta (1999) examined behavioural intention and usage behaviour. In their study, social influence was represented by internalisation and identification processes. These two variables were linked to attitude and behavioural intention. They found that attitude was influenced by perceived usefulness, internalisation, and identification. Further, intention was significantly influenced by perceived usefulness and attitude. In contrast, internationalisation and identification insignificantly influenced intention. in other word, social influence failed to predict behavioural intention. Perceived usefulness, trust, and perceived risk were predictor variables used by Belkhamza and Wafa (2015) to predict intention of e-commerce use among Algerian consumers. One of the results they reached that the perceived usefulness had an important impact on adoption intention. Accordingly, the authors posit that:

$\mathrm{H}_{2}$ - Perceived usefulness has an important impact on attitude towards adoption.

$\mathrm{H}_{3}$ - Perceived usefulness has an important impact on e-money adoption intention.

\subsubsection{Social influence, perceived usefulness, and adoption intention}

Social influence is defined as "the degree to which an individual perceives that other important persons believe he or she should use the technology/system" (Venkatesh et al., 2003, p. 451). Prior studies reported that social influence had a significant impact on perceived usefulness and behavioural intention(Kleijnen et al., 2004; Kulviwat et al., 2009; Sabah, 2016). Kulviwat et al. (2009) studied intention of students at a university in the USA to adopt high-tech innovation products. These scholars linked social influence on attitude towards behaviour and adoption intention. They found that social influence had a significant impact on attitude and adoption intention and attitude had a significant impact on adoption intention. This study was supported by Wang and Lin (2011) who investigated bloggers' intention. They provided that social influence had a crucial impact on adoption intention. A study conducted by Yang et al. (2012) measured adoption intention relating to mobile payment services. They compared between users and non-users and included three predictor variables including social influence, personal traits, and behavioural beliefs. They explained that there was a significant impact on adoption intention both users and non-users in terms of social influence. Kleijnen et al. (2004) employed perceived usefulness, perceived ease of use, attitude, perceived cost, social influence, and perceived systems quality to predict consumer acceptance of wireless financial transactions. Some of the findings said that perceived usefulness had a significant effect on attitude, and attitude and social influence had a significant effect on adoption intention. In Lu et al. (2005)'s study, social influence consisted of subjective norms and image. They predicted intention of mobile phone users in the USA to predict intention to use wireless internet service via mobile technology by employing social influence, innovativeness, perceived ease of use, and perceived usefulness. One of the findings they carried out was that social influence insignificantly influenced adoption intention. Perceived usefulness was one of the predictor variables chose by Venkatesh and Davis (2000). This variable was linked to adoption intention. In this study, social influence was separated into two different variables: subjective norm and image. Further, both these two variables were linked to perceived usefulness. Based on their calculation, they found that subjective norm and image influenced perceived usefulness significantly. They also mentioned that perceived usefulness influenced adoption intention significantly. Furthermore, Sabah (2016) explored factors that could influence m-learning adoption. In their study, they found that social influence significantly predicted perceived usefulness and adoption intention. They also reported that perceived usefulness significantly predicted adoption intention. These studies discussed above lead the authors to hypothesise that: 
$\mathrm{H}_{4}$ - Social influence has an important impact on perceived usefulness.

$\mathrm{H}_{5}$ - Social influence has an important impact on e-money adoption intention.

\subsection{Theoretical framework}

Fig. 1 presents the theoretical framework to be tested. In this model, attitude is linked to adoption intention (Ayeh et al., 2013; Hsu \& Lin, 2008; Kleijnen et al., 2004; Kulviwat et al., 2009; Malhotra \& Galletta, 1999). Moreover, perceived usefulness is linked to attitude and adoption intention (Ayeh et al., 2013; Belkhamza \& Wafa, 2015; Malhotra \& Galletta, 1999; Venkatesh $\&$ Davis, 2000). Furthermore, social influence is connected to perceived usefulness (Venkatesh \& Davis, 2000) and adoption intention (Kleijnen et al., 2004; Kulviwat et al., 2009; Lu et al., 2005; Wang \& Lin, 2011).

$\underset{\text { Serceived usefulness }}{\stackrel{\text { Attitude }}{\longrightarrow}}$

\section{Research method}

Fig. 1. The theoretical framework

\subsection{Sample}

Participants of this current study were approached conveniently through an electronic personal communication mode particularly using WhatsApp, Line, and BlackBerry Messengers. The authors obtained a help from students of the university where the authors' works were to spread an online instrument to their networks. The online instrument was developed using Qualtrics, an online survey provider.

\subsection{Measures}

All indicators employed in this study were adapted from existing studies. Perceived usefulness and attitude towards adoption were measured adapting indicators from Davis (1989). Further, social influence was measured using indicators adapted from Yoo and Lee (2009) and intention to adopt e-money was measured adapting indicators from Nasri (2011), Yu (2009), and Zhou (2011). Attitude was measured using a seven-point of semantic differential scale. Perceived usefulness, social influence, and adoption intention were measured using a seven-point of Likert's scale ranging from 1 for strongly disagree to 7 for strongly disagree. The instrument was written in Bahasa (language) Indonesia to be distributed in Indonesia, and in Turkish language to be distributed in Turkey.

\subsection{Data analysis}

In this current study, the authors took three steps to analyze the data. The first step was exploratory factor analysis. By doing this, dimensions of each variable were formed (if any), and indicators were validated. The second step was to measure the reliability of constructs. Constructs with Cronbach's alpha larger than 0.6 would be considered reliable (Hair et al., 2006). The third stage was to calculate structural equation model (SEM) to examine hypotheses. A fitness should be achieved with a probability score of 0.05 (Schermelleh-Engel et al., 2003) and a CMIN/DF score of $\leq 2$ (Tabachnick \& Fidell, 2007). Besides, the fitted model should have a CFI score of $\geq 0.97$ (Hu \& Bentler, 1995) and a RMSEA score of $\leq 0.05$ (Hu \& Bentler, 1999).

\section{Results and discussion}

\subsection{Participants}

In the case of Indonesia, 264 participants involved in this study containing 168 females (63.6\%) and 96 males (36.4\%) (See Table 1). Predominant participants were in the age between 16-25 years old. In detail, 191 participants were in the age between 16-20 years old (72.3\%) and 60 participants were in the age between $21-25$ years old (22.7\%). Regarding marital status, 256 participants (97\%) were married, six participants $(2.3 \%)$ were single, and the rests were separated. Additionally, 213 participants $(81.3 \%)$ graduated from high school, 35 participants $(13.3 \%)$ held a bachelor certificate, and the rests held a post-grad, diploma, and less than a higher school. Furthermore, 192 participants (72.7\%) claimed that they were still in a school/university, 25 participants were employed (9.5\%), 26 participants were employed while studying, and the rests were unemployed. For the case of Turkey, 318 participants took part. However, only 287 of them completed the instrument consisting of 176 females $(61.3 \%)$ and 111 males (38.7\%). The majority of participants were aged between 21 and 25 years old (194 participants; 67.6\%). All participants were students of a university and predominant of them were not married. Only three of them were separated (1\%). The majority of them (176 participants) were $67.6 \%)$ and there were unmarried (282 participants; $98.3 \%)$. 
Table 1

Profile of participants

\begin{tabular}{|c|c|c|c|c|c|}
\hline & & \multicolumn{2}{|c|}{ Indonesian case } & \multicolumn{2}{|c|}{ Turkish case } \\
\hline & & Frequency & Percent & Frequency & Percent \\
\hline \multirow[t]{3}{*}{ Sex } & Male & 96 & 36,4 & 111 & 38.7 \\
\hline & Female & 168 & 63,6 & 176 & 61.3 \\
\hline & Total & 264 & 100,0 & 287 & 100.0 \\
\hline \multirow[t]{6}{*}{ Employment status } & Employed & 25 & 9,5 & & \\
\hline & Unemployed & 13 & 4,9 & & \\
\hline & Self-employed & 4 & 1,5 & & \\
\hline & Student & 192 & 72,7 & 287 & 100.0 \\
\hline & Studying while working & 26 & 9,8 & & \\
\hline & Looking for a job & 4 & 1,5 & & \\
\hline \multirow[t]{3}{*}{ Age } & $\geq 26$ & 10 & 0,1 & 4 & 1.3 \\
\hline & $21-25$ & 60 & 22,7 & 194 & 67.6 \\
\hline & $\leq 20$ & 193 & 3,0 & 89 & 31.0 \\
\hline \multirow[t]{3}{*}{ Marital status } & Married/de facto & 6 & 2,3 & & \\
\hline & Unmarried & 256 & 97,0 & 282 & 98.3 \\
\hline & Separated & 1 &, 4 & 3 & 1.0 \\
\hline \multirow[t]{5}{*}{ Education } & Less than high school & 3 & 1,1 & & \\
\hline & High school & 213 & 80,7 & 283 & 98.6 \\
\hline & Diploma & 9 & 3,4 & 4 & 1.4 \\
\hline & Bachelor & 35 & 13,3 & & \\
\hline & Post grad & 2 &, 8 & & \\
\hline
\end{tabular}

\subsection{Exploratory factor analysis}

Exploratory factor analysis has been implemented for four variables and resulted five constructs. Adoption intention had seven indicators with factor loadings ranging from 0.613 to 0.903 . This dimension had a Cronbach's alpha score of 0.927 . Attitude towards adoption possessed ten indicators with factor loadings ranging from 0.598 to 0.829 and a Cronbach's alpha score of 0.929. Further, perceived usefulness survived five indicators with factor loadings ranging from -0.830 to -0.930 . This construct had a Cronbach's alpha score of 0.941 . Social influence had two dimensions. The first dimension kept three indicators with factor loadings ranging from 0.606 to 0.793 and a Cronbach's alpha score of 0.781 . The second dimension retained two indicators with factor loadings of -0.759 and -0.779 . This second dimension had a Cronbach's alpha score of 0.896 .

Table 2

The results of EFA

\begin{tabular}{|c|c|c|c|}
\hline & & Factor loadings & Cronbach's alpha \\
\hline 1 & Adoption intention & & 0.927 \\
\hline In5 & I plan to use electronic money in the future & 0.903 & \\
\hline In6 & If possible, I will try to use electronic money & 0.898 & \\
\hline In3 & I will use electronic money regularly later & 0.871 & \\
\hline In4 & I would advise my friends to use electronic money & 0.870 & \\
\hline In 1 & I will use electronic money as soon as possible & 0.831 & \\
\hline In 2 & I would recommend electronic money to my family members & 0.822 & \\
\hline In7 & I will try to use electronic money if I deem necessary & 0.613 & \\
\hline 2 & Attitude towards adoption & & 0.929 \\
\hline A6 & Practical/Impractical & 0.829 & \\
\hline A12 & Flexible time/Inflexible time & 0.803 & \\
\hline A3 & Positive/Negative & 0.801 & \\
\hline A7 & Save time/Do not save time & 0.795 & \\
\hline A11 & Worth a try/Unworthy a try & 0.794 & \\
\hline A5 & Profitable/Unprofitable & 0.753 & \\
\hline A 10 & Easy to use/Uneasy to use & 0.747 & \\
\hline A1 & Good idea/Bad idea & 0.744 & \\
\hline A13 & Power save & 0.742 & \\
\hline A8 & Safe/Unsafe & 0.598 & \\
\hline 3 & Perceived usefulness & & 0.941 \\
\hline P3 & Generally, electronic money will be useful & -0.930 & \\
\hline $\mathrm{P} 2$ & Using electronic money will increase my effectiveness in financial transactions & -0.924 & \\
\hline P5 & The use of electronic money can help me accomplish the tasks live /work more easily & -0.910 & \\
\hline $\mathrm{P} 1$ & Using electronic money will save time & -0.904 & \\
\hline P4 & e-Money will increase efficiency in financial transactions & -0.830 & \\
\hline 4 & Social influence (1) & & 0.781 \\
\hline S5 & Retailers (such as stores / mini markets / super markets etc.) will support if I use electronic money & 0.793 & \\
\hline S6 & $\begin{array}{l}\text { Service providers (such as salon / barber shop / doctor, contract owner / board, etc.) will support if } \\
\text { I use electronic money }\end{array}$ & 0.781 & \\
\hline S4 & My boss at my office / lecturer on campus / teacher at school will support if I use electronic money & 0.606 & \\
\hline 5 & Social influence (2) & & 0.896 \\
\hline $\mathrm{S} 1$ & Parents will support if I use electronic money & -0.779 & \\
\hline $\mathrm{S} 2$ & My other family members will support if I use electronic money & -0.759 & \\
\hline
\end{tabular}




\subsection{Hypothesis testing}

Fig. 2 shows the structural model examining the theoretical framework above. This model tested all participants both Indonesian and Turkish consumers and achieved a fitness with a probability score of 0.059 , CMIN/DF score of 1.342 , CFI score of 0.995 , and RMSEA score of 0.025 . Further, the authors conducted group analyses test for Indonesian and Turkish consumers (the models are not presented here). In assessing the Indonesian consumers, a fitted model was obtained with a probability score of $0.126, \mathrm{CMIN} / \mathrm{DF}$ score of 1.310 , CFI score of 0.994 , and RMSEA score of 0.034 . In addition, a fitted model of Turkish consumers had a probability score of 0.109 , CMIN/DF score of 1.293 , CFI score of 0.991 , and RMSEA score of 0.032 .

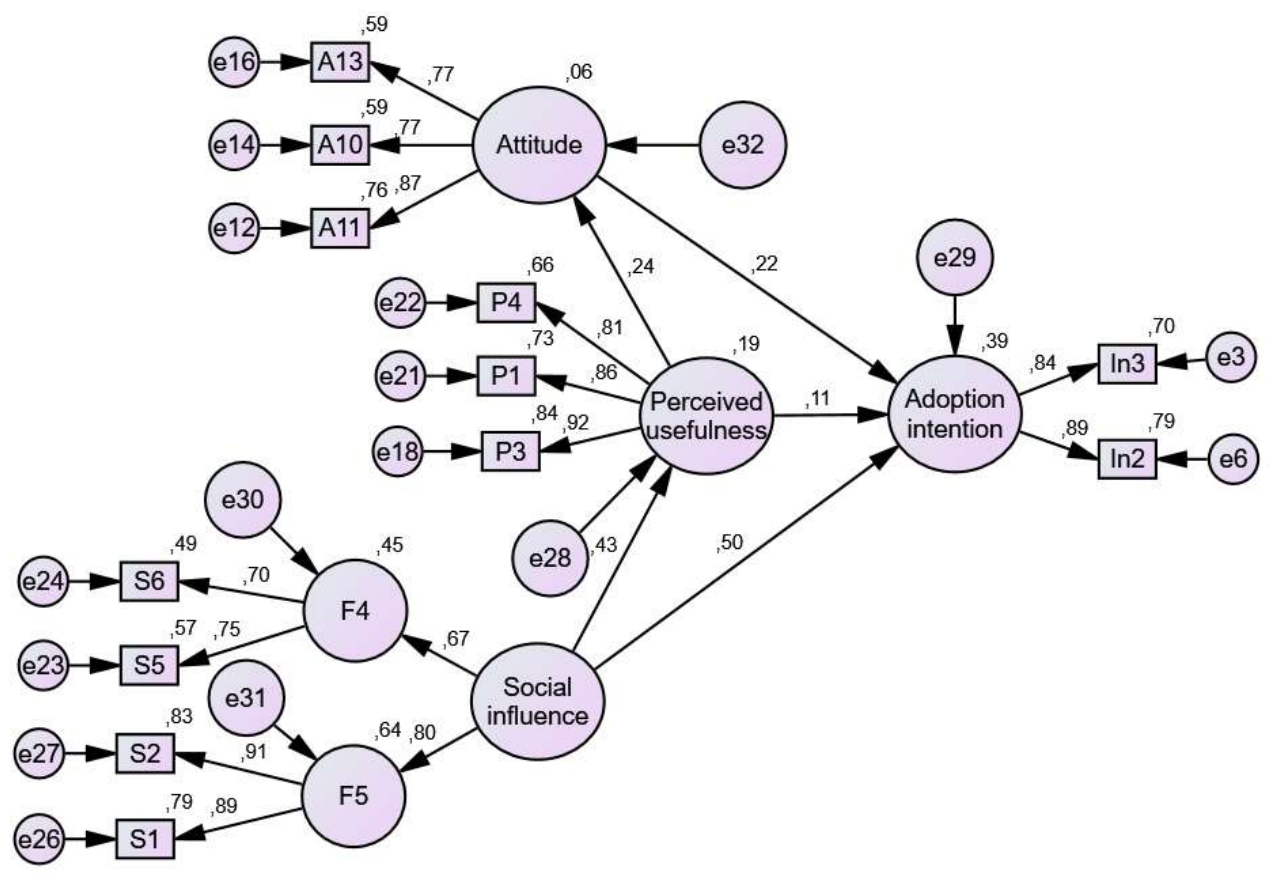

Fig. 2. Structural model of hypotheses testing

Table 3 presents the result summary of hypotheses testing. Based on the calculation, all hypotheses of all participants were greater than 1.96 and are considered significant (Hair Jr. et al., 2006). The results also show the Indonesian and Turkish cases. Of both cases, hypothesis 3 had C.R. scores of 0.596 and 1.107 respectively indicating insignificances.

Table 3

The results of testing the hypotheses

\begin{tabular}{llllcccccc}
\hline & & & \multicolumn{2}{c}{ All cases } & \multicolumn{2}{c}{ Indonesian case } & \multicolumn{2}{c}{ Turkish case } \\
\cline { 3 - 9 } & & & C.R. & P & C.R. & P & C.R. & P \\
\hline $\mathrm{H}_{1}$ & Attitude & $\rightarrow$ & Adoption intention & 4.894 & $* * *$ & 2.318 & 0.020 & 3.542 & $* * *$ \\
$\mathrm{H}_{2}$ & Perceived usefulness & $\rightarrow$ & Attitude & 5.120 & $* * *$ & 4.544 & $* * *$ & 3.291 & 0.001 \\
$\mathrm{H}_{3}$ & Perceived usefulness & $\rightarrow$ & Adoption intention & 1.983 & 0.047 & 0.596 & 0.551 & 1.107 & 0.268 \\
$\mathrm{H}_{4}$ & Social influence & $\rightarrow$ & Perceived usefulness & 6.537 & $* * *$ & 5.479 & $* * *$ & 3.842 & $* * *$ \\
$\mathrm{H}_{5}$ & Social influence & $\rightarrow$ & Adoption intention & 6.395 & $* * *$ & 6.328 & $* * *$ & 3.855 & $* * *$ \\
\hline
\end{tabular}

\subsection{Discussion}

As explained in the beginning of this article, the e-money used as the object of this research is electronic money in the form of cards. In Indonesia and Turkey, there is a fundamental equation of e-money rules, that e-money is a type of card issued by a bank or non-bank. Actually, no big effort required for participants to have an e-money card. They simply go to a bank that publishes e-money and there is no need to also have an account in the bank. In fact, there are some e-money cards that can be purchased in many minimarkets, as well as from individuals who become e-money card salesmen. Indonesia and Turkey are two developing countries that are here, and there are many changes from the things that are traditional to be modern, including concerning the use of payment instruments. Both countries are fighting for a cashless society. e-Money in the last ten years continues to be introduced to the public, both by the government, the banking industry, the telecommunications industry, and the service providers. Currently, regulations are ready, infrastructure is available, and public education on the use of e-money 
continues to be encouraged. It is hoped that this aggressive development can create a positive attitude of the community, including the participants in this study. The more positive the participants' attitudes toward the use of e-money, the stronger the adoption intention of the participants. The first hypothesis predicted the impact of attitude towards adoption on adoption intention. The path had a C.R. score of 5.120 indicating significance. This finding supports prior studies (Ayeh et al., 2013; Badrinarayanan et al., 2014; Hsu \& Lin, 2008; Kleijnen et al., 2004; Kulviwat et al., 2009; Malhotra \& Galletta, 1999). For the case of Indonesia and Turkey, the models achieved C.R. scores of 2.318 and 3.542 respectively. These values were also significant. The second hypothesis predicted the impact of perceived usefulness on attitude towards adoption. This result is promoted by existing studies (Ayeh et al., 2013; Kleijnen et al., 2004; Malhotra \& Galletta, 1999). e-Money becomes mandatory when participants want to use the services of trains, buses, and entering highways. If the participants do not have emoney, they cannot take the train, bus, and enter the toll road. Some parking areas in shopping centers and offices, though not obligatory, but the managers of the buildings have offered the use of e-money for parking rental payments. Including modern stores, they have installed machines that can make their customers pay faster and easier. This condition has an impact on the positive attitude of participants towards the use of e-money. The need to use e-money does not seem to build the sincerity of participants to use e-money. Participants do not well appreciate Even e-money's ease of use, so it does not provide a stimulus to participants' intentions to adopt e-money technology.

Person's positive attitude toward e-money should increase the intention to adopt e-money technology. The third hypothesis predicted the effect of perceived usefulness on adoption intention. When two sample groups from Indonesia and Turkey were united, a value of C.R was generated. of 1,983. This value shows significance although not too large. However, when viewed per case, it turns out that perceived usefulness cannot have a significant effect on participants' intention to use e-money. In the Indonesian case, the path had a C.R. score of 0.596, and in the Turk case, the path obtained a C.R. score of 1.107. Both values were considered insignificant as less than 1.96 than expected. Therefore, both hypotheses were rejected. These findings were in contrast with the previous studies (Ayeh et al., 2013; Belkhamza \& Wafa, 2015). Social influence seems to have an important role in determining participants' perceptions of the usefulness of e-money. The fourth hypothesis predicted the impact of social influence on perceived usefulness. In the three models, the path had C.R. scores of 6.537, 5.479, and 3.842 respectively. These findings supported prior studies (Ayeh et al., 2013; Belkhamza \& Wafa, 2015; Malhotra \& Galletta, 1999; Venkatesh \& Davis, 2000). In this case, the stronger the influence of retailers, service providers, closest people in the environment of participants, parents, and families in supporting participants to use e-money, the more positive the perception of e-money. Social influence also gives positive direction to adoption intention participants. The fifth hypothesis predicted the impact of social influence on adoption intention. Some scholars have inspected this path (Kleijnen et al., 2004; Kulviwat et al., 2009; Wang \& Lin, 2011; Yang et al., 2012). In this study, the path had a C.R. score of 6.845, and therefore, the hypothesis was accepted. When the benefits of e-money are felt by the service providers so that they continue to use these items to transact with their customers and even governed by regulations, both government and bank regulations, there is no other option for the service provider to keep e-money as a tool payment. If all parties have agreed while the infrastructure to implement this means of payment is readily available, then this ecosystem will be very easy to pressure stakeholders to collaborate using e-money. So, the greater the social influence felt by the participants, the stronger the influence will be on the participants' intention to use e-money.

\section{Conclusion}

The use of e-money in a form of a card for financial transactions broadens and increases by Indonesian consumers including for shopping, paying bills, and buying tickets. This movement is a part of national campaign initiated by the Indonesian and Turkish governments to promote a cashless society. This study intended to measure the impact of attitude, social influence, and perceived usefulness on e-money adoption intention in Indonesia and Turkey. In total, three similar models were tested: the first model included all participants, the second model consisted of Indonesian consumers, and the third model contained Turk consumers. In the first model, attitude towards adoption had an important effect on adoption intention. In addition, social influence had a significant impact on perceived usefulness and adoption intention. Further, perceived usefulness had a significant influence on attitude and adoption intention. In the second and third models, perceived usefulness failed to predict adoption intention. In this paper, a number of limitations deserve to be highlighted. This study supposed to focus only on the adoption intention of e-money for optional financial transactions. In Indonesia and Turkey, the surrounding cities where data for this study were collected, the use of e-money is mandatory, especially for public transportation. This is one of the limitations of this study. Another limitation of this study is that the participants were chosen conveniently. Therefore, the results cannot generalize all situations relating to e-money adoption intention. Another concern would be the variance associated with the variables. In order to enhance accuracy and generalizability of the findings, a larger sample size across different geographical locations and countries should be considered in future studies.

Since the Technology Acceptance Model states that perceived usefulness of a technology is influenced by its perceived ease of use. So, future studies should consider perceived usefulness and possibly other variables of e-money applications such as convertibility, anonymity, reliability, traceability, efficiency and applicability. It is also possible to include the demographic profiles of the respondents with the factors influencing users' perception toward e-money so that appropriate target e-money applications can be identified. Another possible area would be to determine the differences between the users' expectations and the actual e-money experience so that a gap analysis can be conducted. 


\section{References}

Ayeh, J. K., Au, N., \& Law, R. (2013). Predicting the intention to use consumer-generated media for travel planning. Tourism Management, 35, 132-143.

Badrinarayanan, V., Becerra, E. P., \& Madhavaram, S. (2014). Influence of congruity in store-attribute dimensions and selfimage on purchase intentions in online stores of multichannel retailers. Journal of Retailing and Consumer services, 21(6), 1013-1020.

Belkhamza, Z., \& Wafa, S. A. (2015). The effect of perceived risk on the intention to use e-commerce: The case of Algeria. The Journal of Internet Banking and Commerce, 2009.

Davis, F. D. (1989). Perceived usefulness, perceived ease of use, and user acceptance of information technology. MIS quarterly, 319-340.

European Central Bank. (1998). Report on electronic money Retrieved from https://www.ecb.europa.eu/pub/pdf/other/emoneyen.pdf.

Gunawan, H. (2015). BI to promote e-money transactions in 2015 (in Bahasa Indonesia). Retrieved from Kontan.co.id website: http://english.kontan.co.id/news/bi-to-promote-e-money-transactions-in-2015

Hair Jr., J. F., Black, W. C., Babin, B. J., Anderson, R. E., \& Tatham, R. L. (2006). Multivariate data analysis (6 ed.). New Jersey: Prentice-Hall, Inc.

Hsu, C.-L., \& Lin, J. C.-C. (2008). Acceptance of blog usage: The roles of technology acceptance, social influence and knowledge sharing motivation. Information \& Management, 45(1), 65-74.

Hu, L.-t., \& Bentler, P. M. (1995). Evaluating model fit. In R. H. Hoyle (Ed.), Structural equation modeling. Concepts, issues, and applications (pp. 76-99). London: Sage.

Hu, L.-t., \& Bentler, P. M. (1999). Cutoff criteria for fit indexes in covariance structure analysis: Conventional criteria versus new alternatives. Structural Equation Modeling: A Multidisciplinary Journal, 6(1), 1-55.

Kleijnen, M., Wetzels, M., \& De Ruyter, K. (2004). Consumer acceptance of wireless finance. Journal of Financial Services Marketing, 8(3), 206-217.

Kulviwat, S., Bruner, G. C., \& Al-Shuridah, O. (2009). The role of social influence on adoption of high tech innovations: The moderating effect of public/private consumption. Journal of Business Research, 62(7), 706-712.

Lu, J., Yao, J. E., \& Yu, C.-S. (2005). Personal innovativeness, social influences and adoption of wireless Internet services via mobile technology. The Journal of Strategic Information Systems, 14(3), 245-268.

Lukman, E. (2014). Here are 17 emoney options Indonesians can use for shopping, travel, and ecommerce. Retrieved from Tech in Asia website: https://www.techinasia.com/17-emoney-options-indonesia

Malhotra, Y., \& Galletta, D. F. (1999). Extending the technology acceptance model to account for social influence: Theoretical bases and empirical validation. Paper presented at the Systems sciences, 1999. HICSS-32. Proceedings of the 32nd annual Hawaii international conference on.

Miliani, L., Purwanegara, M. S., \& Indriani, M. T. D. (2013). Adoption behavior of e-money usage. Information Management and Business Review, 5(7), 369.

Nasri, W. (2011). Factors influencing the adoption of internet banking in Tunisia. International Journal of Business and Management, 6(8), 143-160.

Osah, O., \& Kyobe, M. (2017). Predicting user continuance intention towards M-pesa in Kenya. African Journal of Economic and Management Studies, 8(1), 36-50.

Sabah, N. M. (2016). Exploring students' awareness and perceptions: Influencing factors and individual differences driving m-learning adoption. Computers in Human Behavior, 65, 522-533.

Schermelleh-Engel, K., Moosbrugger, H., \& Müller, H. (2003). Evaluating the fit of structural equation models: Tests of significance and descriptive goodness-of-fit measures. Methods of Psychological Research Online, 8(2), 23-74.

Szajna, B. (1996). Empirical evaluation of the revised technology acceptance model. Management science, 42(1), 85-92.

Tabachnick, B. G., \& Fidell, L. S. (2007). Using multivariate statistics (5 ed.). Boston Pearson/Allyn \& Bacon.

Venkatesh, V., \& Davis, F. D. (2000). A theoretical extension of the technology acceptance model: Four longitudinal field studies. Management science, 46(2), 186-204.

Venkatesh, V., Morris, M. G., Davis, G. B., \& Davis, F. D. (2003). User acceptance of information technology: Toward a unified view. MIS quarterly, 27(3), 425-478.

Wahyuningsih, R. (2016). Already have e-money? These tpes and lstings of many favorite products (in Bahasa Indonesia). Retrieved from Cermati website: https://www.cermati.com/artikel/sudah-punya-e-money-ini-jenis-dan-daftar-produkyang-banyak-digemari

Wang, S.-m., \& Lin, J. C.-C. (2011). The effect of social influence on bloggers' usage intention. Online Information Review, 35(1), 50-65.

Yang, S., Lu, Y., Gupta, S., Cao, Y., \& Zhang, R. (2012). Mobile payment services adoption across time: An empirical study of the effects of behavioral beliefs, social influences, and personal traits. Computers in Human Behavior, 28(1), 129-142.

Yoo, B., \& Lee, S.-H. (2009). Buy genuine luxury fashion products or counterfeits? NA-Advances in Consumer Research Volume 36.

Yu, S. (2009). Factors influencing the use of mobile banking: The case of SMS-based mobile banking. AUT University.

Zhou, T. (2011). The effect of initial trust on user adoption of mobile payment. Information Development, 27(4), 290-300. 
(C) 2020 by the authors; licensee Growing Science, Canada. This is an open access article distributed under the terms and conditions of the Creative Commons Attribution (CCBY) license (http://creativecommons.org/licenses/by/4.0/). 